\title{
Tindakan Tembak Mati Terhadap Terduga Teroris Berdasarkan Perspektif Proses Hukum Yang Adil
}

\author{
July Wiarti \\ Pascasarjana Hukum UII Yogyakarta \\ Jln. Cik Di Tiro No. 1 Yogyakarta \\ julywiarti@law.uir.ac.id
}

\begin{abstract}
The process of law enforcement for the criminal acts of terrorism that should have been carried out from investigation to execution is often cut down to violations by the authorities, namely the Special Detachment (Densus) 88, such as arbitrary arrest, wrongful arrest and suspected death-shooting of terrorists without proper procedures. Based on these, the research will discuss two issues, first, how is the process of determining someone declared a terrorist suspect? Second, how is the implementation of the act of shooting to death suspected terrorists by Densus 88 in the perspective of due process of law? This study uses a normative juridical method which the data collection method is done through literature study and analyzed in descriptive-qualitative manner. The conclusions of this research are, first, the process of determining a person is declared a suspected terrorist is that a person suspected of having committed or attempted to commit, or participating in and/or facilitating a criminal act of terrorism is based on sufficient preliminary evidence, which is required at least 2 (two) valid evidence. Second, the execution of the act of death-shooting against the suspected terrorists by Densus 88 in the perspective of due process of law is when the authorities use firearms at the last step and may only be used for urgent conditions and preceded by a warning.
\end{abstract}

Key Words: Criminal act of terrorism; Densus 88; due process of law

\begin{abstract}
Abstrak
Proses penegakan hukum tindak pidana terorisme yang seharusnya dilaksanakan dari penyidikan hingga eksekusi seringkali dipangkas hingga terjadi pelanggaran oleh aparat yakni Densus 88 seperti penangkapan yang semena-mena, salah tangkap dan menembak mati terduga teroris tanpa prosedur yang benar. Berdasarkan hal tersebut, maka penelitian ini akan membahas dua permasalahan, yaitu pertama, bagaimana proses penetapan seseorang dinyatakan sebagai terduga teroris? Kedua, bagaimana pelaksanaan tindakan tembak mati terhadap terduga teroris oleh densus 88 dalam perspektif due process of law? Penelitian ini menggunakan metode yuridis normatif dengan metode pengumpulan data yaitu studi pustaka dan dianalisis secara deskriptif-kualitatif. Simpulan penelitian ini yaitu, pertama, proses penetapan seseorang dinyatakan sebagai terduga teroris, yakni orang yang diduga telah melakukan atau mencoba melakukan, atau ikut serta dan/atau memudahkan suatu tindak pidana terorisme adalah berdasarkan pada bukti permulaan yang cukup, yakni diperlukan sekurangkurangnya 2 (dua) alat bukti yang sah. Kedua, pelaksanaan tindakan tembak mati terhadap terduga teroris oleh densus 88 dalam perspektif due process of law adalah ketika aparat menggunakan senjata api pada langkah terakhir dan hanya boleh digunakan untuk kondisi yang mendesak dan didahului dengan peringatan.
\end{abstract}

Kata-kata Kunci : Densus 88; tindak pidana terorisme; due process of law 


\section{Pendahuluan}

Negara Indonesia adalah negara hukum, ${ }^{1}$ hal ini sesuai dengan yang terdapat di dalam Undang-Undang Dasar 1945 yang selanjutnya disingkat dengan UUD NRI 1945, yang mana berbunyi: "Negara Republik Indonesia adalah negara hukum."2 Konsekuensinya adalah suatu negara dalam menjalankan aktifitas kenegaraannya harus berdasarkan pada hukum. Hal ini diwujudkan dengan munculnya undangundang atau ketentuan tertulis seperti yang penulis kemukakan sebelumnya.

Pelaksanaan negara hukum tersebut salah satunya dengan adanya hukum pidana yang mengatur perilaku warga negara. Dalam hukum pidana ${ }^{3}$ perbuatan yang dilarang diatur di dalam undang-undang dan bagi yang melanggar akan dikenakan sanksi pidana. ${ }^{4}$ Perbuatan yang dilarang itu disebut dengan tindak pidana, salah satu tindak pidana itu adalah seperti melakukan teror atau yang lebih dikenal lagi dengan tindak pidana terorisme.

Di Indonesia khususnya untuk tindak pidana terorisme diatur pada undangundang tersendiri. Awalnya, tindak pidana terorisme diatur dalam bentuk Peraturan Pemerintah Pengganti Undang-Undang yaitu Nomor 1 Tahun 2002 tentang Pemberantasan Tindak Pidana Terorisme. Kemudian ditetapkan menjadi undang-undang yaitu Undang-Undang Nomor 15 Tahun 2003 tentang Penetapan Peraturan Pemerintah Pengganti Undang-Undang Nomor 1 Tahun 2002 tentang Pemberantasan Tindak Pidana Terorisme, Menjadi Undang-Undang. Maka dari itu, negara berwenang untuk menghukum mereka yang melakukan aksi teror sebagaimana diatur dalam undang-undang tersebut.

${ }^{1}$ Negara hukum yang dimaksud tersebut masuk ke dalam konsep rechtsstaat. Sebagaimana yang disampaikan oleh Ni'matul Huda dalam bukunya yang berjudul ilmu negara: "Konsep rechtsstaat bertumpu atas sistem hukum kontinental yang disebut civil law." Ni'matul Huda, Imu Negara, Rajawali Pers, Jakarta, 2010, hlm. 93.

${ }^{2}$ Lihat Undang-Undang Dasar 1945 Pasal 1 ayat (3).

${ }^{3}$ Hukum pidana adalah bagian dari keseluruhan hukum yang berlaku di suatu negara, yang mengadakan dasar-dasar dan aturan-aturan untuk:

1) Menentukan perbuatan-perbuatan mana yang tidak boleh dilakukan, yang dilarang, dengan disertai ancaman atau sanksi yang berupa pidana tertentu bagi barang siaa melanggar larangan tersebut.

2) Menentukan kapan dan dalam hal-hal apa kepada mereka yang telah melangggar larangan-larangan itu dapat dikenakan atau dijatuhi pidana sebagaimana yang telah diancamakan.

3) Menentukan dengan cara bagaimana pengenaan pidana itu dapat dilaksanakan apabila ada orang yang disangka telah melanggar larangan tersebut. Moeljatno, Asas-Asas Hukum Pidana, Rineka Cipta, Jakarta, 2008, hlm. 1.

4 Ada yang menyebut pidana dan hukuman. Pidana menurut Prof Roeslan Saleh adalah reaksi atas delik yang banyak berwujud suatu nestapa yang dengan sengaja ditimpakan negarra pada pembuat delik. Sedangkan hukum menurut R. Soesilo adalah suatu perasaan tidak enak (sengsara) yang dijatuhkan oleh hakim dengan vonis, kepada orang-orang yang melanggar undang-undang hukum pidana. Bambang Waluyo, Pidana dan Pemidanaan, Sinar Grafika, Jakarta, 2008, hlm. 9. 
Proses untuk menghukum mereka yang melakukan kejahatan terorisme tersebut harus melewati tahapan hingga akhirnya diberikan hukuman, dalam hukum acara pidana pada umumnya itu dikenal beberapa tahapan seperti: penyelidikan, penyidikan, penuntutan, persidangan, dan pelaksanaan pidana. Penegakan hukum terhadap kejahatan terorisme ini masih terdapat permasalahan.

Pada prakteknya, penanganan tindak pidana terorisme oleh negara kerap kali terjadi pelanggaran. Diantaranya berkenaan mengenai seseorang yang diduga sebagai teroris, yakni dalam hal ini kerap terjadinya kesalahan terhadap orang yang ditangkap atau dikenal juga dengan (error in persona) yang dalam prakteknya tidak jarang juga ditembak mati atau sebelumnya telah mendapat tindakan kekerasan.

Sebagaimana yang disampaikan oleh Direktur The Community of Islamic Ideology Analyst (CIIA), ia menyatakan bahwa "Kita hitung berapa yang mati setiap ada operasi dan proses penangkapan terduga teroris," untuk kasus salah tangkap, setidaknya lebih dari 40 orang dan 99 persen dari mereka yang salah tangkap ini mengalami penyiksaan. Dikatakan Haris, data tersebut baru hasil monitoring yang ia lakukan hampir setiap tahun. ${ }^{5}$

Berikut salah satu kasus yang penulis temukan:6 Detasemen Khusus (Densus) 88 Antiteror menangkap 4 orang di Solo pada Selasa 29 Desember 2015. Namun ternyata 2 di antaranya menjadi korban salah tangkap. Dua orang yang merupakan korban salah tangkap Densus 88 bernama Ayom Panggalih dan Nur Syawaludin. Saat proses penangkapan, kedua orang itu mendapatkan perlakukan yang kurang manusiawi oleh pihak Densus. Bahkan, mereka sempat ditodong pistol oleh pasukan antiteror tersebut. Penangkapan kedua terduga teroris tersebut tergolong penangkapan yang sewenang-wenang dan kurang manusiawi karena dilakukan dengan kekerasan dan proses yang tidak selayaknya seperti proses penangkapan melainkan seperti proses penculikan.

5 http://nasional.republika.co.id/berita/nasional/hukum/16/03/13/o3z8ou394-pengamat-ada-puluhankorban-salah-tangkap-densus-88, "Pengamat: Ada Puluhan Korban Salah Tangkap Densus 88," Akses 12 September 2016.

6http://news.liputan6.com/read/2401439/kronologi-salah-tangkap-densus-88-di-solo, "Kronologi Salah Tangkap Densus 88 di Solo," Akses 12 September 2016. 


\section{Ifx Renaissance No. 1 VOL. 4 JANUARI 2019: 1 - 24}

Tentu mau tidak mau dengan fakta tersebut, dapat dilihat bahwa adanya kemungkinan yang salah dari Densus 88 dalam menetapkan seseorang sebagai terduga teroris. Dalam setahun saja Densus 88 bisa salah untuk menangkap seseorang yang benar-benar terlibat dalam tindak pidana terorisme tersebut. Sehingga perlu dikaji ulang bagaimana proses penetapan seseorang dinyatakan sebagai terduga teroris. Perlu dikaji karena ketika seseorang telah ditangkap dengan dugaan telah melakukan tindak pidana terorisme, maka akan banyak hakhaknya yang dirampas salah satunya hak kebebasan.

Menurut Sekretaris (The Islamic State and Acin Center) yang selanjutnya disebut ISAC mencatat sepuluh orang ditembak mati karena diduga terlibat terorisme. Menurut mereka penangkapan dengan menembak mati tersangka terorisme dilakukan tidak sesuai prosedur. Penangkapan tidak disertai surat penangkapan dan biasanya disertai kerusakan. ${ }^{7}$

Fakta yang terlihat adalah dalam prosesnya aparat penegak hukum dalam hal ini Densus 88, banyak yang melakukan melakukan tembak mati pada pelaku atau terduga teroris. Hal ini tentu saja bertentangan dengan due process of law. Terlebih lagi mengingat bahwa setiap manusia memiliki hak untuk hidup, namun apabila diharuskan untuk ditembak mati sebagai sebuah hukuman, maka harus melalui proses yang ada dan dengan adanya putusan pengadilan yang memiliki kekuatan hukum tetap (Inkracht Van geweisde), meskipun di sisi lain, keberadaan hukuman mati hingga saat ini masih terus diperdebatkan.

Tindakan tembak mati yang dilakukan aparat penegak hukum di sini dapat dikategorikan sebagai extra judicial killing yaitu diartikan sebagai tindakantindakan, apa pun bentuknya, yang menyebabkan seseorang mati tanpa melalui proses hukum dan putusan pengadilan yang dilakukan oleh aparat negara. ${ }^{8}$ Ciri pentingnya adalah: ${ }^{9}$

1) melakukan tindakan yang menimbulkan kematian;

2) dilakukan tanpa melalui proses hukum yang sah;

3) pelakunya adalah aparat negara;

7 Redaksi An-najah, "Korban Salah Tangkap Terorisme Tak Pernah Dapatkan Hal Rehabilitasi \& Permintaan Maaf”, dalam http://www.an-najah.net/2013/01/korban-salah-tangkap-terorisme-tak-pernahdapatkan-hak-rehabilitasi-permintaan-maaf-/, akses 11 Januari 2016.

${ }^{8}$ Mahrus Ali, Hukum Pidana Terorisme Teori dan Praktik, Gramata Publishing, Jakarta, 2012, hlm. 71-72.

${ }^{9}$ Ibid. 
4) tindakan yang menimbulkan kematian tersebut tidak dilakukan dalam keadaan membela diri atau melaksanakan perintah undang-undang.

Segala ketentuan mengenai pelaksanaan hukum pidana tersebut diatur dalam Undang-Undang Nomor 8 Tahun 1981 tentang Hukum Acara Pidana yang selanjutnya disingkat dengan KUHAP. Due Process of law adalah konsep yang mendasari pembentukan KUHAP itu sendiri, dan inilah yang membedakannya dengan Het Herziene Inlandsch Reglement atau yang dikenal dengan H.I.R. Due process of law memberikan jaminan dan perlindungan terhadap harkat dan martabat manusia yang lebih baik. Salah satu wujudnya adalah dengan yang mana dalam pelaksanaan proses hukum pidana tersebut harus tetap memperhatikan hak-hak manusia salah satunya hak untuk hidup.

Melihat pada fakta yang ada di atas, terlihat bahwa Densus 88 masih bertindak seenaknya dan bahkan dengan gampangnya mencabut hak hidup mereka para terduga teroris, padahal di dalam KUHAP telah dimuat perlindungan terhadap manusia itu sendiri, seperti hak hidup. Lantas bagaimana pelaksanaan tindakan tembak mati tersebut dilihat dari prinsip due process of law yang mendasari konsep KUHAP tersebut.

\section{Rumusan Masalah}

Berdasarkan pada latar belakang masalah di atas, didapatlah beberapa hal yang menjadi masalah, yaitu sebagai berikut: Pertama, bagaimana proses penetapan seseorang dinyatakan sebagai terduga teroris? Kedua, bagaimana pelaksanaan tindakan tembak mati terhadap terduga teroris oleh Densus 88 dalam perspektif due process of law?

\section{Tujuan Penelitian}

Penelitian ini bertujuan untuk: pertama, mengetahui proses penetapan seseorang dinyatakan sebagai terduga teroris. Kedua, untuk menganalisis pelaksanaan tindakan tembak mati terhadap terduga teroris oleh Densus 88 dalam perspektif due process of law. 


\section{$6 \quad$ Inx Renaissance No. 1 VOL. 4 JANUARI 2019: 1 - 24}

\section{Metode Penelitian}

Penelitian ini merupakan penelitian yuridis normatif atau disebut juga sebagai penelitian hukum doktrinal. Penelitian ini menggunakan tiga jenis bahan hokum, yaitu bahan hukum primer berupa peraturan perundang-undangan seperti Undang-Undang Dasar Negara Republik Indonesia Tahun 1945, Kitab UndangUndang Hukum Acara Pidana, dan UU Terorisme. Bahan hukum sekunder berupa bahan hukum lain yang mendukung bahan hukum primer seperti jurnal, buku, laporan, penelitian yang relevan. Bahan hukum tersier seperti kamus hukum. Untuk menguatkan bahan hukum tersebut, digunakan juga penggalian data melalui wawancara yang dilakukan peneliti ke beberapa narasumber yang kompeten di bidangnya. Data yang digunakan dikumpulkan melalui metode studi pustaka dan dianalisis secara deskriptif-kualitatif untuk menjawab rumusan masalah.

\section{Hasil Penelitian dan Pembahasan}

\section{Proses Penetapan Seseorang Dinyatakan Sebagai Terduga Teroris}

Terduga teroris diartikan sebagai mereka yang diduga telah melakukan atau mencoba melakukan, atau ikut serta dan/atau memudahkan suatu tindak pidana terorisme. M. Abdul Kholiq mengungkapkan, bahwa terduga definisinya dalam konseptual yuridis normatif tidak ada, tidak ada konsep seperti tersangka, terdakwa, terpidana seperti dalam KUHAP. Kata terduga terinspirasi dari katakata yang dikutip dari Pasal 28 Undang-Undang Pemberantasan Tindak Pidana Terorisme. Diduga keras maknanya dikaitkan dengan Pasal 26, yaitu ketika dengan bukti permulaan awal yang sebenarnya tidak cukup karena hanya berupa data intelijen, tetapi telah dilegal audit lalu akhirnya dianggap cukup. Jadi ukurannya seseorang itu dianggap terduga ketika dengan bukti intelijen saja yang sudah diaudit ketua pengadilan setempat. Jadi sepanjang dengan itu dinyatakan dinilai terlibat Tindak Pidana Terorisme itulah terduga. ${ }^{10}$

Berdasarkan pada hasil wawancara yang penulis lakukan dengan Irmawansyah, ia menjelaskan bahwa yang dimaksud dengan terduga teroris, adalah seseorang yang karena perbuatannya atau keadaannya berdasarkan bukti

10 Wawancara dengan M. Abdul Kholiq, Dosen Fakultas Hukum UII dan Pascasarjana UII, di Kampus Fakultas Hukum UII Taman Siswa, Yogyakarta, 24 September 2016. 
permulaan patut diduga sebagai pelaku tindak pidana terorisme, aturannya adalah Undang-Undang RI Nomor 15 Tahun 2003 tentang Pemberantasan Tindak Pidana Terorisme. ${ }^{11}$ Sehingga dari keterangan di atas dapat diambil kesimpulan bahwa terduga teroris adalah orang yang patut diduga melakukan tindak pidana berdasarkan pada bukti permulaan yang cukup.

Bagaimana sebenarnya proses penetapan seseorang tersebut dinyatakan sebagai terduga teroris? Hal ini sangat penting untuk dikaji mengingat efek yang ditimbulkan atau akibat yang ada dari status terduga teroris adalah sangat besar bagi kehidupan seseorang tersebut. Maka dari itu, penetapan seseorang sebagai terduga teroris juga harus berprinsip pada due process of law. Due process of law pada dasarnya diartikan sebagai suatu proses hukum yang harus dilaksanakan dengan adil, yakni menerapkan aturan beracara sebagaimana mestinya dan harus memperhatikan hakhak tersangka atau terdakwa atau terpidana.

Berdasarkan ketentuan yang ada, yakni menurut Undang-Undang Pemberantasan Tindak Pidana Terorisme dijelaskan bahwa Penyidik dapat melakukan penangkapan terhadap setiap orang yang diduga keras melakukan tindak pidana terorisme berdasarkan bukti permulaan yang cukup sebagaimana dimaksud dalam Pasal 26 ayat (2) untuk paling lama 7 × 24 jam. Pada Pasal 26 diterangkan beberapa hal sebagai berikut:

a. Untuk memperoleh Bukti Permulaan yang cukup, penyidik dapat menggunakan setiap 'Laporan Intelijen.'

b. Penetapan bahwa sudah dapat atau diperoleh Bukti Permulaan yang cukup sebagaimana dimaksud dalam ayat (1) harus dilakukan proses pemeriksaan oleh Ketua dan Wakil Ketua Pengadilan Negeri.

c. Proses pemeriksaan sebagaimana dimaksud dalam ayat (2) dilaksanakan secara tertutup dalam waktu paling lama tiga (3) hari.

d. Jika dalam pemeriksaan sebagaimana maksud dalam ayat (2) ditetapkan adanya Bukti Permulaan yang cukup, maka Ketua Pengadilan Negeri segera memerintahkan dilaksanakan Penyidikan.

Berdasarkan ketentuan di atas, maka pihak yang dapat ditangkap adalah orang yang telah memenuhi standar untuk dikatakan sebagai terduga teroris.

${ }^{11}$ Wawancara dengan Kompol Irmawansyah, S.H., Kanit Handak Subdit I Kamneg Ditreskrimum POLDA DIY, Yogyakarta, 24 Oktober 2016. 


\section{IEx Renaissance No. 1 VOL. 4 JANUARI 2019: 1 - 24}

Untuk melakukan penangkapan terhadap seseorang yang diduga teroris tersebut harus berpegang pada bukti permulaan yang cukup, dalam hal ini yaitu dapat menggunakan laporan intelijen yang telah dilakukan proses pemeriksaan oleh Ketua atau Wakil Ketua Pengadilan Negeri atas perintah Ketua Pengadilan Negeri lah baru dapat dilaksanakan Penyidikan.

Yang dimaksud dengan "laporan intelijen" adalah laporan yang berkaitan dan berhubungan dengan masalah-masalah keamanan nasional. Laporan intelijen dapat diperoleh dari Departemen Dalam Negeri, Departemen Luar Negeri, Departemen Pertahanan, Departemen Kehakiman dan HAM, Departemen Keuangan, Kepolisian Negara Republik Indonesia, Tentara Nasional Indonesia, Kejaksaan Agung Republik Indonesia, Badan Intelijen Negara, atau instansi lain yang terkait. ${ }^{12}$ Undang-Undang Pemberantas Tindak Pidana Terorisme memandang bahwa bukti permulaan cukup adalah berupa laporan intelijen yang dapat diperoleh dari instansi tersebut.

Ed Suradji mengungkapkan bahwa menurut Pasal 26 ayat (2), (3) dan (4) Undang-Undang Nomor 15 Tahun 2003 tentang Pemberantasan Tindak Pidana Terorisme, adanya Laporan Intelijen sebagai bukti permulaan yang cukup, yang penetapan sahnya memerlukan penetapan Pengadilan Negeri, seolah-olah Laporan Intelijen itu sebagai primary evidence (bukti pokok). Penetapan tersebut dilakukan dengan proses atau mekanisme secara tertutup. Hal ini mengakibatkan pihak intelijen mempunyai dasar hukum yang kuat untuk melakukan penangkapan terhadap seseorang yang dianggap melakukan suatu tindak pidana terorisme, tanpa adanya pengawasan masyarakat atau pihak lain manapun. Padahal kontrol sosial dibutuhkan terutama terhadap perlindungan hak-hak orang sebagai manusia yang sifatnya asasi, tidak dapat diganggu gugat. ${ }^{13}$

Ed Suradji melihat bahwa dengan menjadikan laporan intelijen sebagai bukti permulaan cukup yang mana prosesnya dilakukan secara tertutup, membuat masyarakat atau pihak lain tidak dapat untuk ikut melakukan pengawasan

\footnotetext{
12 Penjelasan Pasal 26 ayat (1) Undang-Undang Nomor 15 Tahun 2003 tentang Pemberantasan Tindak Pidana Terorisme.

${ }^{13}$ Ed Suradji, Analisis dan Evaluasi Peraturan Perundaang-Undangan tentang Pemberantasan Tindak Pidana Terorisme (Undang-Undang Nomor 15 Tabun 2003), Badan Pembinaan Hukum Nasional Kementerian Hukum dan Hak Asasi Manusia RI, Jakarta, 2012, hlm. 79.
} 
terhadap proses penetapan seseorang sebagai terduga teroris. ${ }^{14}$ Mungkin inilah yang menyebabkan banyaknya juga terjadi Densus 88 yang salah menangkap orang yang diduga sebagai teroris. Dari pemaparan di atas dapat dilihat bahwa penetapan terduga teroris berdasarkan pada bukti permulaan yang cukup yang lebih lanjut dijelaskan dapat berupa laporan intelijen.

Irmawansyah mengatakan bahwa proses untuk menetapkan seseorang berstatus sebagai terduga teroris apabila terpenuhi minimal 2 alat bukti. Data dapat diperoleh dari hasil informasi masyarakat, penyelidikan/pengembangan kasus, media elektronik dan lain-lain. ${ }^{15}$ Sehingga menurutnya terduga teroris adalah ketika terpenuhinya bukti permulaan yang cukup yakni pada dua alat bukti. Makna dari bukti permulaan yang cukup ini tentu perlu dikaji dengan lebih serius mengingat bahwa inilah yang dapat menetapkan posisi seseorang itu sebagai terduga teroris atau tidak.

Pada aturan umumnya, penangkapan di dalam KUHAP dimaknai jika seseorang itu diduga keras melakukan tindak pidana berdasarkan bukti permulaan yang cukup. Lebih lanjut, di dalam penjelasannya diterangkan bahwa bukti permulaan yang cukup ialah bukti permulaan untuk menduga adanya tindak pidana sesuai dengan bunyi Pasal 1 butir 14. Pasal ini menunjukkan bahwa perintah penangkapan tidak dapat dilakukan dengan sewenang-wenang, tetapi ditujukan kepada mereka yang betul-betul melakukan tindak pidana. ${ }^{16}$ Adapun bunyi Pasal 1 butir 14 adalah "tersangka yakni seseorang yang karena perbuatannya atau keadaannya, berdasarkan bukti permulaan patut diduga sebagai pelaku tindak pidana." Dari KUHAP di atas, tidak ada gambaran secara pasti apa itu bukti permulaan yang cukup.

Bukti permulaan yang cukup sebagai elemen yang berfungsi sebagai prasyarat aparat untuk melakukan penyidikan dan menetapkan status tersangka. Ukuran bukti permulaan yang cukup ini berdasarkan pada Surat Keterangan Bersama (SKB) yang dikeluarkan 21 Maret 1984 yang diinisiasi 4 institusi penegak

\footnotetext{
${ }^{14}$ Ibid

15 Wawancara dengan Kompol Irmawansyah, S.H., Op. Cit.

16 Penjelasan Pasal 17 Undang-undang Nomor 8 Tahun 1981 tentang Hukum Acara Pidana.
} 
hukum: Ketua Mahkamah Agung, Menteri Kehakiman, Jaksa Agung, dan Kepala Kepolisian Republik Indonesia, sebagai hasil Rapat Kerja Gabungan MAKEHJAPOL-I (Rakergab Makehjapol) tentang Peningkatan Koordinasi Dalam Penanganan Perkara Pidana. Salah satu topik bahasan dalam Rakergab Makehjapol tersebut adalah mengenai "bukti permulaan yang cukup" sebagai persyaratan dalam penangkapan menurut pasal 17 KUHAP. 17

Dalam rapat tersebut telah diinventaris 4 (empat) buah pendapat tentang bukti permulaan yang cukup, yaitu: ${ }^{18}$

a. Laporan polisi saja;

b. Laporan polisi ditambah BAP saksi/BAP di TKP/Laporan Hasil Penyidikan/barang bukti;

c. Laporan Polisi ditambah BAP saksi dan BAP di TKP/Laporan hasil penyidikan/barang bukti; dan

d. Laporan polisi ditambah seluruh bukti lainnya.

Terhadap keempat pendapat tersebut, Rakergab Makehjapol memutuskan bahwa: bukti permulaan yang cukup seyogyanya Laporan Polisi ditambah salah satu alat bukti lainnya. ${ }^{19}$ Sehingga bukti permulaan cukup ini dapat diperoleh berupa laporan polisi dan ditambah dengan bukti lain.

Jika dihubungkan dengan Tindak Pidana Terorisme, maka yang dimaksud bukti permulaan yang cukup adalah dua alat bukti baik laporan intelijen ataupun tidak. Dari sinilah baru dapat menetapkan seseorang tersebut terduga teroris atau tidak. Sehingga untuk menetapkan seseorang sebagai terduga teroris, harus adanya dua bukti permulaan yang cukup dapat berupa laporan intelijen atau seperti yang diatur pada Pasal 27 UU Pemberantasan Tindak Pidana Terorisme. Selain itu, berdasarkan Pasal 26 ayat (2) UU Pemberantasan Tindak Pidana Terorisme menekankan bahwa penetapan sudah diperolehnya bukti permulaan yang cukup harus melalui proses pemeriksaan oleh Ketua atau Wakil Ketua Pengadilan Negeri. Sehingga, proses untuk menetapkan seseorang sebagai terduga pelaku tindak pidana terorisme tidaklah instan.

${ }_{17}$ Chandra M. Hamzah, Penjelasan Hukum tentang Bukti Permulaan yang Cukup, PSHK \& Australian Aid, Jakarta, 2014, hlm. 8 - 9

${ }^{18}$ Ibid., hlm. 9

${ }^{19}$ Ibid 
Penjelasan umum UU Pemberantasan Tindak Pidana Terorisme menyebutkan, bahwa UU tersebut memuat ketentuan khusus tentang perlindungan terhadap hak asasi tersangka atau terdakwa yang disebut safe guarding rules. Ketentuan tersebut antara lain memperkenalkan lembaga hukum baru dalam hukum acara pidana yang disebut dengan hearing dan berfungsi sebagai lembaga yang melakukan legal audit terhadap seluruh dokumen atau laporan intelijen yang disampaikan oleh penyelidik untuk menetapkan diteruskan atau tidaknya suatu penyidikan atas dugaaan adanya tindakan terorisme. ${ }^{20}$

Berdasarkan keterangan di atas dan melihat pada prakteknya saat ini sangat bertolak belakang. Hal ini dibuktikan dengan sering terjadinya peristiwa salah tangkap oleh Densus 88, yang juga membuktikan bahwa lembaga itu tidak berperan sebagaimana mestinya dan keberadaanya juga masih perlu dipertanyakan. Tidak jarang dalam proses penangkapan, Densus 88 melakukan aksi salah tangkap disebabkan data yang diberikan tidak akurat. Mengenai hal ini Irmawansyah mengungkapkan, bahwa bila ada kesalahan dalam penangkapan seseorang terduga teroris dapat terjadi akibat kurangnya informasi pada saat penyelidikan sebelum tindakan kepolisian dilakukan. ${ }^{21}$

Maka dari itu, untuk menetapkan seseorang sebagai terduga teroris selain harus berdasarkan dua bukti permulaan yang cukup tersebut, juga harus dapat memastikan kebenaran data yang ada. Sehingga tidak ada hak-hak dari orang yang diduga sebagai teroris yang dilanggar. Inilah bentuk dari perwujudan due process of law dalam hal penetapan terduga teroris. Jika ada kesalahan dalam penetapan terduga teroris ini, maka orang tersebut dapat mengajukan praperadilan sebagai cara untuk melindungi hak asasi manusianya. Dalam proses penangkapannya pun aparat juga harus memperhatikan hak-hak terduga teroris sehingga tidak ada yang dilanggar.

${ }^{20}$ R. Wiyono, Pembahasan Undang-Undang Pemberantasan Tindak Pidana Terorisme, Sinar Grafika, Jakarta, 2014, hlm. 195-196.

21 Wawancara dengan Kompol Irmawansyah, S.H., Op. Cit. 


\section{Pelaksanaan Tindakan Tembak Mati Terhadap Terduga Teroris oleh Densus 88 Dalam Perspektif Due Process Of Law}

Agar hukum dipatuhi oleh masyarakat, dalam suatu negara hukum, hukum haruslah benar. Hukum yang benar tersebut harus pula ditegakkan secara benar. Doktrin pelaksanaan hukum yang benar ini populer dengan sebutan due process of law. Secara historis, istilah due process of law mempunyai konotasi bahwa segala sesuatu harus dilakukan secara adil. Konsep due process of law sebenarnya terdapat dalam konsep hak-hak (fundamental fundamental rights) dan konsep kemerdekaan/kebebasan yang tertib (ordered liberty). ${ }^{22}$ Di sini due process of law diwujudkan sebagai pelaksanaan hukum yang benar, dilakukan secara adil dan berkaitan dengan konsep hak-hak.

Due process of law dalam kasus tembak mati terduga teroris oleh Densus 88 belum dapat dikatakan terpenuhi. Karena tindakan tembak mati tidak dapat disamakan dengan hukuman mati yang terdapat pada Pasal 10 KUHP. ${ }^{23}$ Tembak mati merupakan tindakan menembak mati orang yang terlibat dalam suatu kejahatan yang berupa langkah inisiatif aparat dalam rangka proses penegakan hukum yang dilakukan sesuai dengan aturan yang berlaku. Sedangkan hukuman mati merupakan hukuman yang diberikan pada pelaku kejahatan setelah adanya putusan pengadilan yang memiliki kekuatan hukum tetap (Inkracht Van geweisde), yang eksekusinya dilakukan oleh pihak yang berwenang seperti yang diatur dalam KUHP yaitu dilakukan oleh algojo. ${ }^{24}$

Menghilangkan nyawa seseorang yang terlibat dalam suatu kejahatan harus dilakukan oleh pihak yang berwenang sebagaimana diatur dalam undang-undang dan berdasar pada putusan pengadilan yang memiliki kekuatan hukum tetap (Inkracht Van geweisde). Berkenaan mengenai tindakan tembak mati ini, maka juga harus dilakukan dengan berdasarkan ketentuan hukum yang ada.

Aturan-aturan yang berkenaan dengan penggunaan senjata api dapat dilihat pada Peraturan Kapolri Nomor 1 Tahun 2009 tentang Penggunaan Kekuatan

${ }^{22}$ Munir Fuady, Teori Negara Hukum Modern (Rechtstaat), PT Refika Aditama, Bandung, 2009, hlm. 46.

${ }^{23}$ Pasal 10 Kitab Undang-undang Hukum Pidana berbunyi: Pidana terdiri atas: a. Pidana pokok: 1. Pidana mati; 2. Pidana penjara; 3. Kurungan; 4. Denda.

${ }^{24}$ Diatur pada Pasal 11 KUHP yang berbunyi: pidana mati dijalankan oleh algojo pada tempat gantungan dengan menjeratkan tali yang terikat di tiang gantungan pada leher terpidana kemudian menjatuhkan papan tempat terpidana berdiri. 
Dalam Tindakan Kepolisian dan Peraturan Kapolri Nomor 8 Tahun 2009 tentang Implementasi Prinsip Dan Standar Hak Asasi Manusia dalam Penyelenggaraan Tugas Kepolisian Negara Republik Indonesia. Pada kedua aturan tersebut dapat disimpulkan bahwa penggunaan kekuatan itu dapat dibenarkan. Penggunaan kekuatan adalah segala penggunaan daya, potensi, kemampuan anggota polri dalam rangka melaksanakan tindakan kepolisian. ${ }^{25}$ Tahapan penggunaan kekuaatan ini pun terbagi dalam tahapan, yaitu: ${ }^{26}$

a. Tahap 1 kekuatan yang memiliki dampak pencegahan;

b. Tahap 2 perintah lisan;

c. Tahap 3 kendali tangan kosong lunak;

d. Tahap 4 kendali tangan kosong keras;

e. Tahap 5 kendali senjata tumpul, senjata kimia, (gas air mata, semprotan cabe) atau alat lain sesuai standar polisi;

f. Tahap 6 menggunakan senjata api atau alat lain yang dapat menghentikan pelaku yang dapat menyebabkan luka parah atau kematian anggota polri atau masyarakat.

Peraturan Kapolri Nomor 8 Tahun 2009 dalam Pasal 47 menyatakan senjata api bagi petugas hanya boleh digunakan untuk menghadapi keadaan luar biasa; membela diri dari ancaman kematian dan/atau luka berat; membela orang lain terhadap ancamana kematian dan/atau luka berat; mencegah terjadinya kejahatan berat atau yang mengancam jiwa orang; menahan, mencegah atau menghentikan seseorang yang sedang atau akan melakukan tindakan yang sangat membahayakan jiwa; dan mengangani situasi yang membahayakan jiwa, dimana langkah-langkah yang lebih lunak tidak cukup.

Peraturan Kepala Kepolisian Negara Republik Indonesia Nomor 1 Tahun 2009 tentang Penggunaan Kekuatan Dalam Tindakan Kepolisian dalam Pasal 8 ayat (1) menyebutkan penggunaan kekuatan dengan kendali senjata api atau alat lain dilakukan ketika tindakan pelaku kejahatan atau tersangka dapat secara segera menimbulkan luka parah atau kematian bagi anggota Polri atau masyarakat; anggota Polri tidak memiliki alternatif lain yang beralasan dan masuk akal untuk

\footnotetext{
${ }^{25}$ Lihat Pasal 1 Poin 3 Peraturan Kapolri Nomor 1 Tahun 2009 tentang Penggunaan Kekuatan Dalam Tindakan Kepolisian

${ }^{26}$ Lihat Pasal 5 ayat (1) Peraturan Kapolri Nomor 1 Tahun 2009 tentang Penggunaan Kekuatan Dalam Tindakan Kepolisian
} 


\section{Lx Renaissance No. 1 VOL. 4 JANUARI 2019: 1 - 24}

menghentikan tindakan/perbuatan pelaku kejahatan atau tersangka tersebut; anggota Polri sedang mencegah larinya pelaku kejahatan atau tersangka yang merupakan ancaman segera terhadap jiwa anggota Polri atau masyarakat.

Pasal 48 huruf b Peraturan Kapolri Nomor 8 Tahun 2009 tentang Implementasi Prinsip dan Standar Hak Asasi Manusia dalam Penyelenggaraan Tugas Kepolisian Negara Republik Indonesia menyebutkan, sebelum menggunakan senjata api, polisi harus memberikan peringatan yang jelas dengan cara berupa menyebutkan dirinya sebagai petugas atau anggota Polri yang sedang bertugas; memberi peringatan dengan ucapan secara jelas dan tegas kepada sasaran untuk berhenti, angkat tangan, atau meletakkan senjatanya; dan memberi waktu yang cukup agar peringatan dipatuhi. Pada huruf c menyebutkan, hal-hal di atas boleh untuk tidak dilakukan jika dalam keadaan yang sangat mendesak dimana penundaan waktu diperkirakan dapat mengakibatkan kematian atau luka berat bagi petugas atau orang lain disekitarnya.

Pasal 15 Peraturan Kepala Kepolisian Negara Republik Indonesia Nomor 1 Tahun 2009 tentang Penggunaan Kekuatan Dalam Tindakan Kepolisian menyebutkan pula dalam hal tindakan pelaku kejahatan atau tersangka dapat menimbulkan bahaya ancaman luka parah atau kematian terhadap anggota Polri atau masyarakat atau dapat membahayakan keselamatan umum dan tidak bersifat segera, dapat dilakukan tembakan peringatan. Tembakan peringatan tidak diperlukan ketika menangani bahaya ancaman yang dapat menimbulkan luka parah atau kematian bersifat segera, sehingga tidak memungkinkan untuk dilakukan tembakan peringatan. Tembakan peringatan ini dilakukan ke udara dan ke tanah.

Pada Pasal 49 Peraturan Kapolri Nomor 8 Tahun 2009 tentang Implementasi Prinsip dan Standar Hak Asasi Manusia dalam Penyelenggaraan Tugas Kepolisian Negara Republik Indonesia dijelaskan pula setelah melakukan penindakan dengan menggunakan senjata api, petugas wajib: mempertanggungjawabkan tindakan penggunaan senjata api; memberi bantuan medis bagi setiap orang yang terluka tembak; memberitahukan kepada keluarga atau kerabat korban akibat penggunaan senjata api; dan membuat laporan terinci dan lengkap tentang penggunaan senjata api. Dalam hal terdapat pihak yang merasa keberatan atau dirugikan akibat 
penggunaan senjata api oleh petugas, maka: petugas wajib membuat penjelasan secara rinci tentang alasan penggunaan senjata api, tindakan yang dilakukan dan akibat dari tindakan yang telah dilakukan; pejabat yang berwenang wajib memberikan penjelasan kepada pihak yang dirugikan; dan tindakan untuk melakukan penyidikan harus dilaksanakan sesuai dengan peraturan perndangundangan.

Pasal 14 Peraturan Kepala Kepolisian Negara Republik Indonesia Nomor 1 Tahun 2009 tentang Penggunaan Kekuatan Dalam Tindakan Kepolisian menyebutkan setiap pelaksanaan tindakan kepolisian yang menggunakan kekuatan kendali tangan kosong keras; kendali senjata tumpul, senjata kimia antara lain gas air mata, semprotan cabe atau alat lain sesuai standar Polri; kendali dengan menggunakan senjata api atau alat lain anggota Polri yang melaksanakan penggunaan kekuatan wajib secara segera melaporkan pelaksanaannya kepada atasan langsung secara tertulis dalam bentuk formulir penggunaan kekuatan.

Berdasarkan pada aturan-aturan yang ada di atas, tidak ada secara eksplisit yang menjelaskan dibenarkannya tindakan tembak mati dan tidak ada gambaran tentang bagian mana dari tubuh si tersangka atau pelaku yang diperbolehkan untuk ditembak dengan maksud bukan untuk menembak mati. Pada aturan di atas hanya menerangkan diperbolehkannya menggunakan senjata api yakni dalam keadaan yang sesuai dengan yang dipersyaratkan, kemudian dibenarkannya untuk dilakukan tembakan peringatan dan inipun dilakukan ke udara dan ke tanah, serta mengharuskan aparat yang menembak untuk bertanggung jawab atas tindakannya dalam menggunakan senjata api.

Prosedur Tetap Kapolri No. Pol : PROTAP/01/V/2001 tentang Penggunaan Senjata Api menyebutkan Prosedur Tindakan :

1. Prosedur. Pemegang senjata api harus orang yang sudah dinyatakan lulus dalam ujian Psikologi dan uji keterampilan, ini menyangkut aspek emosional, kepribadian dan keterampilan penggunaan senjata api.

2. Tindakan dan Persyaratan Penggunaan Senjata Api. Penggunaan senjata api hanya dibenarkan dilakukan petugas dalam keadaan terpaksa, untuk membela diri (petugas) ataupun melindungi / menyelamatkan jiwa raga seseorang (masyarakat) dari setiap ancaman / gangguan kejahatan. 
3. Tujuan Penggunaan Senjata Api. Pada prinsipnya penggunaan senjata api bertujuan untuk melumpuhkan pelaku kejahatan bukan untuk mematikan sehingga ancaman terhadap keselamatan jiwa petugas maupun jiwa seseorang dapat dicegah dan pelaku kejahatan dapat ditangkap.

4. Sasaran Tembak. Sesuai dengan tujuan penggunaan senjata api sasaran tembak diarahkan kepada organ / bagian tubuh seseorang yang tidak vital / tidak mematikan seperti kepala, jantung, mata, dll. Organ tidak vital seperti kaki. Dalam keadaan rusuh massal, sasaran tembak diprioritaskan / ditujukan terhadap pemimpin / penggerak kerusuhan.

5. Tahapan Tindakan. Penggunaan senjata api tidak langsung ditujukan / diarahkan terhadap pelaku kejahatan / pelanggar hukum, tetap diawali dengan tindakan peringatan sebanyak 3 (tiga) kali, baik menggunakan peluru tajam, karet maupun dengan tembakan salvo (keatas).

6. Kewenangan Pemberian Perintah. Dalam formasi pasukan Dalmas/PHH (Pasukan Huru Hara) penggunaan senjata api (peluru tajam) hanya diberlakukan atas perintah Kepala Satuan Kewilayahan, serendahrendahnya Kapolres/Ta.

Berdasarkan pada Protap tersebut, dengan jelas disebutkan bahwa penggunaan senjata api hanya dalam keadaan terpaksa, untuk membela diri (petugas) ataupun melindungi / menyelamatkan jiwa raga seseorang (masyarakat) dari setiap ancaman / gangguan kejahatan. Penggunaan senjata api bertujuan untuk melumpuhkan pelaku kejahatan bukan untuk mematikan, dengan ini menegaskan bahwa penggunaannya hanya untuk melumpuhkan dengan tujuan sasaran tembak bagian tubuh seseorang yang tidak vital / tidak mematikan seperti kaki dan tidak boleh menjadikan sasaran seperti kepala, jantung, mata, dll. Penggunaan senjata api tetap diawali dengan tindakan peringatan sebanyak 3 (tiga) kali, baik menggunakan peluru tajam, karet maupun dengan tembakan salvo (keatas). Sehingga tidak ada aturan yang dengan eksplisit menyebutkan dibolehkannya dilakukan tindakan tembak mati. Tetapi berdasarkan pada The Basic Principles on The Use of Force and Firearms (BPUFF) merupakan instrumen yang diterima oleh Kongres Perserikatan Bangsa-Bangsa kedelapan pada tahun 1990 tentang pencegahan kejahatan dan perlakuan terhadap para pelanggar hukum, Penggunaan senjata api yang mematikan hanya boleh dilakukan apabila sangat tak dapat dihindarkan untuk melindungi hidup.

KUHAP Pasal 5 ayat (1) huruf a poin ke empat dan Pasal 7 ayat (1) huruf $j$, disebutkan bahwa penyelidik dan penyidik dapat mengadakan tindakan lain 
menurut hukum yang bertanggung jawab. Pada penjalasan KUHAP lebih lanjut dijelaskan tindakan lain adalah tindakan dari penyelidik maupun penyidik untuk kepentingan penyelidikan dan penyidikan dengan syarat: a) tidak bertentangan dengan suatu aturan hukum; b) selaras dengan kewajiban hukm yang mengharuskan dilakukannya tindakan jabatan; c) tindakan itu harus patut dan masuk akal dan termasuk dalam lingkungan jabatannya; d) atas pertimbangan yang layak berdasarkan keadaan memaksa; e) menghormati hak asasi manusia. Dari ketentuan yang di dalam KUHAP pun melegalkan aparat untuk melakukan tindakan lain, asal terpenuhinya syarat-syarat tersebut.

Irmawansyah mengungkapkan, bahwa tidak dibenarkan untuk dilakukan tembak mati kecuali dalam hal terduga teroris pada saat dilakukan tindakan kepolisian melakukan perlawanan yang dapat membahayakan keselamatan jiwa petugas atau masyarakat dan kerusakan harta benda. ${ }^{27} \mathrm{Di}$ sini ia menegaskan bahwa tindakan dapat dilakukan jika ada perlawanan dari terduga teroris.

Berdasarkan pada Peraturan Kapolri Nomor 8 Tahun 2009 tentang Implementasi Prinsip dan Standar HAM dalam Penyelenggaraan Tugas Kepolisian Negara RI diatur bahwa dalam menerapkan tugas pelayanan dan perlindungan terhadap warga masyarakat setiap anggota polri wajib memperhatikan salah satunya yaitu asas proposionalitas tindakan petugas yang seimbang antara tindakan yang dilakukan dengan ancaman yang dihadapi dalam penegakan hukum. ${ }^{28}$ Maka, jika pelaku kejahatan tidak menggunakan senjata api sama sekali, seharusnya anggota polri juga bisa melakukan penegakan hukum tanpa menggunakan senjata api, kecuali jika pelaku memang tidak dapat ditangani lagi. Sehingga kembali lagi ditekankan bahwa penggunaan senjata api hanya sebagai langkah akhir.

Irmawansyah mengatakan, tidak ada perintah atau pelaksanaan tindakan tembak ditempat, yang ada adalah tindakan kepolisian berdasarkan ketentuan Perkap Nomor 01 Tahun 2009 tentang Penggunaan Kekuatan, kewenangan

\footnotetext{
${ }^{27}$ Wawancara dengan Kompol Irmawansyah, S.H., Op. Cit.

${ }^{28}$ Lihat Pasal 9 ayat (1) dan (4) Peraturan Kapolri Nomor 8 Tahun 2009 tentang Implementasi Prinsip dan Standar HAM dalam Penyelenggaraan Tugas Kepolisian Negara RI.
} 
anggota untuk melakukan penilaian sendiri dalam UU No. 2 Tahun 2002, Pasal 48, 49 KUHP. Inilah menurutnya tindakan kepolisian yang dalam hal untuk melakukan tindakan berupa melumpuhkan terduga teroris dengan cara membunuh yang berprinsip kepada due process of law. ${ }^{29}$

Berbagai penjabaran yang ada di atas, memang tidak ada yang secara eksplisit menyebutkan tentang tembak mati, namun hanya mengatur bahwa anggota polri diperbolehkan untuk menggunakan senjata api ketika ada situasi tertentu. Sebelum menggunakan senjata api, polisi harus memberikan peringatan tetapi dalam keadaan yang sangat mendesak dimana penundaan waktu diperkirakan dapat mengakibatkan kematian atau luka berat bagi petugas atau orang lain disekitarnya peringatan dapat diabaikan. Protap 01/V/2001 menyatakan penggunaan senjata api bertujuan untuk melumpuhkan pelaku kejahatan bukan untuk mematikan dan terlebih dahulu ada tindakan tembakan peringatan sebanyak 3 kali. The Basic Principles on The Use of Force and Firearms (BPUFF) penggunaan senjata api yang mematikan hanya boleh dilakukan apabila sangat tak dapat dihindarkan untuk melindungi hidup. KUHAP juga mengatur wewenang penyelidik dan penyidik dapat mengadakan tindakan lain menurut hukum yang bertanggung jawab asal memenuhi syarat-syarat yang ada di dalam KUHAP. Tidak lupa juga aparat harus memperhatikan asas tugas pelayanan dan perlindungan warga masyarakat. Secara menyuluruhnya memperhatikan asas-asas acara hukum pidana yang ada.

Selain dari pada itu, aparat juga harus memperhatikan dan memenuhi hakhak terduga teroris. Ketika kejahatan atau pelanggaran itu dilakukan oleh negara dalam hal keharusan ia melakukan kewajibannya, maka itu bukan lagi dapat digolongkan pada kejahatan yang ada pada umumnya yang dilakukan oleh masyarakat. Tetapi itu sudah termasuk pada pelanggaran hak asasi manusia.

Salah satu instrumen perlindungan HAM yang perlu diperhatikan oleh Polri yaitu hak setiap orang untuk hidup, mempertahankan hidup serta kehidupannya, bagian HAM yang tidak dapat dikurangi oleh siapapun dan dalam keadaan apapun salah satunya hak untuk hidup. ${ }^{30}$ Dalam UUD 1945 pun menjamin tentang

${ }^{29}$ Wawancara dengan Kompol Irmawansyah, S.H., Op. Cit.

${ }^{30}$ Lihat Pasal 5 ayat (1) dan (2) Peraturan Kapolri Nomor 8 Tahun 2009 tentang Implementasi Prinsip dan Standar HAM dalam Penyelenggaraan Tugas Kepolisian Negara RI. 
hak seseorang untuk hidup. ${ }^{31}$ Untuk mengambil langkah dalam menggunakan senjata api, anggota polri harus memperhatikan bahwa setiap orang bahkan meskipun seseorang tersebut pelaku kejahatan memiliki hak untuk hidup.

Banyak aturan yang mengharuskan aparat menjunjung tinggi Hak Asasi Manusia, seperti yang diatur pada Pasal 4 dan Pasal 9 Undang-Undang Nomor 2 Tahun 2002 tentang Kepolisian Negara Republik Indonesia ${ }^{32}$, tentang hak hidup pada Pasal 5 ayat (1) huruf a dan (2) huruf a Peraturan Kapolri Nomor 8 Tahun 2009 tentang Implementasi Prinsip dan Standar HAM dalam Penyelenggaraan Tugas Kepolisian Negara RI, ${ }^{33}$ dalam hal penangkapan diatur pada Pasal 6 huruf d Peraturan Kapolri Nomor 8 Tahun 2009 tentang Implementasi Prinsip dan Standar HAM dalam Penyelenggaraan Tugas Kepolisian Negara RI. ${ }^{34}$ Dalam Deklarasi Universal Hak Asasi Manusia pasal 3 juga menyebutkan bahwa setiap orang berhak atas kehidupan, kebebasan dan keselamatan sebagai individu.

Salah satu aspek kemanusiaan yang sangat mendasar dan asasi adalah hak untuk hidup dan hak untuk melangsungkan kehidupan, karena hak-hak tersebut diberikan langsung oleh Tuhan kepada setiap manusia. Oleh karena itu, setiap uaya perampasan terhadap nyawa termasuk di dalamnya tindak kekerasan lainnya, pada hakekatnya merupakan pelanggaran HAM yang berat bila dilakukan secara sewenang-wenang dan tanpa dasar pembenaran yang sah menurut hukum dan perundang-undangan yang berlaku. ${ }^{35}$

Keberadaan KUHAP telah mengangkat dan menempatkan tersangka/ terdakwa dalam kedudukan sebagai makhluk Tuhan yang memiliki hakat derajat kemanusiaan yang utuh. Tersangka/terdakwa telah ditempatkan dalam posisi "his

${ }^{31}$ Lihat Pasal 28A Undang-Undang Dasar 1945, yang berbunyi: "setiap orang berhak untuk hidup serta berhak mempertahankan hidup dan kehidupannya."

32 Pasal 4 berbunyi: Kepolisian Negara Republik Indonesia bertujuan menjunjung tinggi HAM. Pasal 9 berbunyi: dalam melakukan tugas dan wewenang berdasar norma hukum, norma agama, kesopanan dan kesusilaan dan menjunjung tinggi HAM dan mengutamakan pencegahan.

33 Pasal 5 (1) huruf a berbunyi: instrument perlindungan HAM yang perlu diperhatikan oleh polri: a. hak setiap orang untuk hidup mempertahankan hidup serta kehidupannya. Pasal 5 (2) huruf a berbunyi: bagian HAM yang tidak dapat dikurangi oleh siapa pun dan dalam keadaan apapun: a. hak untuk hidup.

34 Pasal 6 huruf d berbunyi: hak bebas dari penangkapan sewenang-wenang, hak bebas dari penghilangan secara paksa.

${ }^{35}$ Barda Nawawi Arief, Bunga Rampai Kebijakan Hukum Pidana, dikutip dari Muladi, Hak. Asasi ManusiaHakekat, Konsep \& Implikasinya Dalam Perspektif Hukum \& Masyarakat, PT Refika Aditama, Bandung, 2005) hlm. 121. 
entity and dignity as a human being" yang harus diperlakukan dengan nilai-nilai luhur kemanusiaan. Pada prinsipnya hukum harus ditegakkan, namun tidak boleh dengan mengabaikan hak asasi yang melekat pada tersangka/terdakwa. ${ }^{36}$ Namun sayangnya, meski begitu sampai saat ini hal tersebut masih luput dari pandangan penegak hukum.

Penegasan 10 asas dalam butir 3 Penjelasan Umum KUHAP mengatur perlindungan terhadap kluhuran harjat dan martabat manusia. Mardjono Reksodiptro membedakan kesepuluh asas ini menjadi tujuh asas umum dan tiga asas khusus, yaitu: ${ }^{37}$

a. Asas-asas umum:

1) Perlakuan yang sama dimuka hukum tanpa diskriminasi apapu;

2) Pradug tidak bersalah;

3) Hak untuk memperoleh kompensasi (ganti rugi) dan rehabilitasi;

4) Hak untuk mendapatkan bantuan hukum;

5) Hak kehadiaran terdakwa di muka pengadilan;

6) Peradilan yang bebas dan dilakukan dengan cepat dan sederhana;

7) Peradilan yang terbuka untuk umum.

b. Asas-asas khusus:

1) Pelanggaran atas hak-hak individu (penangkapan, penahanan, pengeledahan dan penyitaan) harus didasarkan pada undang-undang dan dilakukan dengan surat perintah (tertulis);

2) Hak seorang tersangka untuk diberitahu tentang persangkaan dan pendakwaan terhadapnya;

3) Kewajiban pengadilan untukmengendalikan pelaksanaan putusanputusannnya.

Sebagaimana yang telah penulis paparkan dalam bab sebelumnya, hak-hak tersangka di antaranya yang telah dirumuskan dalam Bab VI KUHAP:

a. The right of self incrimination. Tidak seorang pun dapat dipaksa memberikan keterangan yang memberatkan dirinya dalam suatu tindak pidana.

b. "Dilarang mencabut" atau "menghilangkan" (deprive) "hak hidup" (life) "kemerdekaan" (liberty), atau "harta benda" (property) tanpa sesuai dengan ketentuan hukum acara (without due process of law).

c. Setiap orang harus "terjamin hak terhadap diri" (person), "kediaman, suratsurat" atas pemeriksaan dan penyitaan yang "tidak beralasan".

d. "Hak konfrontasi" (the right to confront) dalam bentuk "pemeriksaan silang" (cross examine) dengan orang yang menuduh (melaporkan).

36 Ari Wibowo, Hukum Pidana Terorisme Kebijakan Formulatif Hukum Pidana Dalam Penanggulangan Tindak. Pidana Terorisme di Indonesia, Graha Ilmu, Yogyakarta, 2012, hlm. 49.

${ }^{37}$ Soeharto, Perlindungan Hak Tersangka, Terdakwa, dan Korban Tindak Pidana Terorisme dalam Sistem Peradilan Pidana Indonesia, PT Refika Aditama, Bandung, 2007, hlm. 74. 
e. "Hak memperoleh pemeriksaan (peradilan)" yang cepat (the right to a speedy trial).

f. "Hak perlindungan yang sama" dan "pemeriksaan yang sama dalam hukum" (equal protection and equal treatment of the law).

g. "Hak mendapat bantuan penasihat hukum" (the right to have assistance of counsil) dalam pembelaan diri.

M. Abdul Kholiq mengungkapkan, bahwa pijakan untuk melihat apakah tindakan aparat sudah mencerminkan due process of law dilihat pada prinsip-prinsip hak-hak asasi manusia tersangka/terdakwa yang dijamin Undang-undang, seberapa jauh hak-hak tersangka/terdakwa sebagai pihak yang harusnya dilindungi dan sudah ada ketentuannya dalam perundang-undangan terproteksi atau tidak. ${ }^{38}$

Maka dari itu, tindakan tembak mati terhadap terduga teroris tidaklah melanggar prinsip due process of law, jika aparat telah melaksanakan ketentuanketentuan sebagaimana yang telah penulis paparkan di atas dan tetap menjamin hak-hak terduga teroris tersebut.

\section{Penutup}

Berdasarkan pada hasil penelitian dan pembahasan di atas, maka penulis memberikan kesimpulan sebagai berikut: pertama, proses penetapan seseorang dinyatakan sebagai terduga teroris, yakni orang yang diduga telah melakukan atau mencoba melakukan, atau ikut serta dan/atau memudahkan suatu tindak pidana terorisme adalah berdasarkan pada bukti permulaan yang cukup, yakni diperlukan sekurang-kurangnya 2 alat bukti yang sah baik laporan intelijen dalam hal ini yang telah dilakukan proses pemeriksaan oleh Ketua dan Wakil Ketua Pengadilan Negeri serta atas perintah Ketua Pengadilan Negeri lah baru dapat dilaksanakan Penyidikan atau alat bukti seperti yang dimaksud oleh Pasal 27.

Kedua, pelaksanaan tindakan tembak mati terhadap terduga teroris oleh densus 88 dalam perspektif due process of law adalah ketika aparat menggunakan senjata api pada langkah terakhir dan hanya boleh digunakan untuk mencegah

\footnotetext{
38 Wawancara dengan M. Abdul Kholiq, Op. Cit.
} 


\section{Lx Renaissance No. 1 VOL. 4 JANUARI 2019: 1 - 24}

tindakan pelaku kejahatan atau tersangka dapat secara segera menimbulkan luka parah atau kematian bagi anggota Polri atau masyarakat, anggota Polri tidak memiliki alternatif lain yang beralasan dan masuk akal untuk menghentikan tindakan/perbuatan pelaku kejahatan atau tersangka tersebut, anggota Polri sedang mencegah larinya pelaku kejahatan atau tersangka yang merupakan ancaman segera terhadap jiwa anggota Polri atau masyarakat. Sebelum menggunakan senjata api, polisi harus memberikan peringatan tetapi dalam keadaan yang sangat mendesak dimana penundaan waktu diperkirakan dapat mengakibatkan kematian atau luka berat bagi petugas atau orang lain disekitarnya peringatan dapat diabaikan. Protap 01/V/2001 menyatakan penggunaan senjata api bertujuan untuk melumpuhkan pelaku kejahatan bukan untuk mematikan dan terlebih dahulu ada tindakan tembakan peringatan sebanyak 3 kali. The Basic Principles on The Use of Force and Firearms (BPUFF) penggunaan senjata api yang mematikan hanya boleh dilakukan apabila sangat tak dapat dihindarkan untuk melindungi hidup. KUHAP juga mengatur wewenang penyelidik dan penyidik dapat mengadakan tindakan lain menurut hukum yang bertanggung jawab asal memenuhi syarat-syarat yang ada di dalam KUHAP. Tidak lupa juga aparat harus memperhatikan asas-asas yang ada. Selain dari pada itu aparat harus memperhatikan dan memenuhi hak-hak terduga teroris. Berdasarkan kasus yang ada tersebut sebagian besar aparat yakni densus 88 masih melakukan tindakan yang tidak mencerminkan due process of law.

\section{Daftar Pustaka}

\section{Buku}

Ali, Mahrus, Hukum Pidana Terorisme Teori dan Praktik, Gramata Publishing, Jakarta, 2012.

Fuady, Munir, Teori Negara Hukum Modern (Rechtstaat), PT Refika Aditama, Bandung, 2009.

Huda, Ni'matul, Ilmu Negara, Rajawali Pers, Jakarta, 2010.

Hamzah, Chandra M., Penjelasan Hukum tentang Bukti Permulaan yang Cukup, PSHK \& Australian Aid, Jakarta, 2014

Moeljatno, Asas-Asas Hukum Pidana, Rineka Cipta, Jakarta, 2008. 
Muladi, Hak Asasi Manusia - Hakekat, Konsep E Implikasinya Dalam Perspektif Hukum $\mathcal{E}$ Masyarakat, PT Refika Aditama, Bandung, 2005.

Soeharto, Perlindungan Hak Tersangka, Terdakwa, dan Korban Tindak Pidana Terorisme dalam Sistem Peradilan Pidana Indonesia, PT Refika Aditama, Bandung, 2007.

Suradji, Ed., Analisis dan Evaluasi Peraturan Perundaang-Undangan tentang Pemberantasan Tindak Pidana Terorisme (Undang-Undang Nomor 15 Tahun 2003), Badan Pembinaan Hukum Nasional Kementerian Hukum dan Hak Asasi Manusia RI, Jakarta, 2012.

Waluyo, Bambang, Pidana dan Pemidanaan, Sinar Grafika, Jakarta, 2008.

Wibowo, Ari, Hukum Pidana Terorisme Kebijakan Formulatif Hukum Pidana Dalam Penanggulangan Tindak Pidana Terorisme di Indonesia, Graha Ilmu, Yogyakarta, 2012.

Wiyono, R, Pembahasan Undang-Undang Pemberantasan Tindak Pidana Terorisme, Sinar Grafika, Jakarta, 2014.

\section{Peraturan Perundang-undangan}

Undang-Undang Dasar Negara Republik Indonesia Tahun 1945.

Kitab Undang-Undang Hukum Pidana.

Undang-undang Nomor 8 Tahun 1981 tentang Hukum Acara Pidana; Lembaran Negara Tahun 1981 Nomor 76, Tambahan Lembaran Negara Nomor 3209.

Undang-Undang Nomor 2 Tahun 2002 tentang Kepolisian Negara Republik Indonesia; Tambahan Lembaran Negara Republik Indonesia Nomor 4168.

Undang-Undang Nomor 15 Tahun 2003 tentang Pemberantasan Tindak Pidana Terorisme; Tambahan Lembaran Negara Republik Indonesia Nomor 4284.

Peraturan Kapolri Nomor 1 Tahun 2009 tentang Penggunaan Kekuatan Dalam Tindakan Kepolisian; Berita Negara Republik Indonesia Nomor 6 Tahun 2009.

Peraturan Kapolri Nomor 8 Tahun 2009 tentang Implementasi Prinsip dan Standar HAM dalam Penyelenggaraan Tugas Kepolisian Negara RI; Berita Negara Republik Indonesia Tahun 2009 Nomor 150.

\section{Internet}

http:/ / nasional.republika.co.id/berita/nasional/hukum/16/03/13/o3z8ou394pengamat-ada-puluhan-korban-salah-tangkap-densus-88, "Pengamat: Ada Puluhan Korban Salah Tangkap Densus 88," Akses 12 September 2016.

http:/ / news.liputan6.com/read/2401439/kronologi-salah-tangkap-densus-88-disolo, "Kronologi Salah Tangkap Densus 88 di Solo," Akses 12 September 2016.

Redaksi An-najah, “Korban Salah Tangkap Terorisme Tak Pernah Dapatkan Hal Rehabilitasi \& Permintaan Maaf", dalam http://www.an- 
najah.net/2013/01/korban-salah-tangkap-terorisme-tak-pernahdapatkan-hak-rehabilitasi-permintaan-maaf-/, akses 11 Januari 2016.

\section{Wawancara}

Wawancara dengan M. Abdul Kholiq, Dosen Fakultas Hukum UII dan

Pascasarjana UII, di Kampus Fakultas Hukum UII Taman Siswa, Yogyakarta, 24 September 2016.

Wawancara dengan Kompol Irmawansyah, S.H., Kanit Handak Subdit I Kamneg Ditreskrimum POLDA DIY, Yogyakarta, 24 Oktober 2016. 